\title{
Poder local em Tocantins: domínio e legitimidade em Arraias
}

Magda Suely Pereira Costa

Curso: Doutorado em Sociologia

Data da defesa: 15 de agosto de 2008

Orientadora: Prof ${ }^{\mathrm{a}}$. Dr ${ }^{\mathrm{a}}$. Mariza Veloso Motta Santos 


\section{Resumo}

Esta tese examina o poder local em Arraias, Tocantins, e descreve a dinâmica política e social vigente no município. Conforme argumento, trata-se de um município que, mesmo ao viver mudanças seculares, evidencia formas análogas ao que Max Weber descreve como os domínios tradicional e racional-legal e que são legitimadas pelo recurso de diferentes ordens sociais, a saber: a religiosa, a patriarcal, a da reciprocidade, a político-partidária e a governamental. A base de dados é constituída por informações históricas, etnográficas e estatísticas e por um trabalho de campo que abrange a sede do município tocantinense de Arraias, como também o distrito da Canabrava e o povoado do Mimoso. A partir da análise desse conjunto de dados, concluo que, em Arraias, o poder local é exercido pelos fazendeiros, normalmente políticos, oriundos de linhagens tradicionais que utilizam as diferentes ordens sociais para legitimar o seu domínio sobre a sociedade local. Também enfatizo como, a despeito de tal continuidade política, a Arraias de hoje exibe uma paradoxal dinâmica de transição na qual a mesma sociedade que convive com a cultura da tradicionalidade busca adequar-se à normatização imposta pelo domínio racionallegal moderno. O resultado, argumento, é um movimento reflexivo e marcado por uma consciência crescente da responsabilidade individual e coletiva em promover a autonomia, a liberdade e a democracia. Para compreender essas relações de domínio, retorno à teoria de dominação e poder de Max Weber. Para descrever e evidenciar a instrumentalização do espaço sagrado, as diferentes trocas materiais e simbólicas e as formas pelas quais eleições e ações do Legislativo, Executivo e Judiciário se legitimam no cotidiano do município, também recorro a outros conceitos referentes à dádiva, ao patriarcalismo, ao catolicismo romanizado e rústico, ao sistema eleitoral e ao sistema governamental. Finalizo examinando as festas, em especial, as oficiais e religiosas nas quais diferentes trocas geram uma sacralização do político e concomitante profanação do religioso. Nessa relação, argumento, políticos, religiosos, fazendeiros e linhagens utilizam meios modernizados de negociação 
e reciprocidade para perpetuar uma tradição de exercício do poder sobre a sociedade arraiana. Entretanto, foram verificadas mudanças que têm se afirmado e fortalecido nas últimas décadas. Dentre elas, a atuação mais vigorosa das esferas legislativa e judiciária, a utilização constante das normas constitucionais em prol da cidadania e a maior conscientização da sociedade civil.

Palavras-chave: poder; dominação; legitimidade; mudanças. 